UDC 3:37. 377

\title{
Designing of system of educational task in the disciplines of professional and practical training for future technology teachers and professionals in vocational education
}

\author{
Dubovik L.* \\ Kherson State Agricultural University, Kherson, Ukraine
}

Received: 26.11.2019 Accepted: 14.01 .2020

\begin{abstract}
The article is devoted to the design and technological training of engineering and pedagogical specialists using the system of educational technical tasks. The analysis of the concepts of "task", "educational task", "technical task". The features and content of educational tasks are disclosed. Examples of educational technical problems that are used in teaching subjects of vocational and practical training are given. . The tasks were developed for health education at a higher education (higher education) level, to recognize the specialty of the technology teacher, the education service (on the basis of the Kherson State University) and the specialty of the "State Agency". It is proved that the educational task becomes educational only in conjunction with the previous and subsequent, that is, in the task system. It is demonstrated how each next task must necessarily contain elements of the previous one, however, the conditions for their use, as well as the wording or designation of the previously discussed concepts must be new. Performing repeatedly repeated operations with the same concepts and with a variation in the initial data and the form of posing questions contributes to the development of skills to solve technical problems. It is indicated that the solution of creative problems requires a future specialist to know the basics of various sciences and skills to effectively apply knowledge in each specific situation. In particular, in solving technical problems, students use drawing knowledge (analyzing graphically given conditions of the problem, schematically depicting their sentences), in physics (mechanics, electrics and magnetism, optics), they develop personal abilities for analysis, critical evaluation, generalization, and systematization. The use of educational technical tasks in the training of future specialists is an important element of their creative development, since their solution to technical ones promotes the integrated application of students' knowledge. I'm developing a system of primary technical tasks; l'm thinking for an independent robot and for activating an initial process.
\end{abstract}

Key words: design and technological training, creative technical tasks, vocational training, technical creativity.

\section{Конструювання системи навчальних задач з предметів професійно- практичної підготовки для майбутніх вчителів технології та фрахівців 3 професійної освіти}

\author{
Дубовик Л. П. \\ ДВНЗ «Херсонський державний аграрний університет», Херсон, Україна
}

\begin{abstract}
Анотація. Стаття присвячена конструкторсько-технологічній підготовці фрахівців інженерно-педагогічного напряму за допомогою використання системи навчальних технічних задач. Проведено аналіз змісту понять «задача», «навчальна задача», «технічна задача». Розкрито особливості та зміст навчальних задач. Наведено приклади навчальних технічних задач, що використовуються при викладанні предметів професійнопрактичної підготовки. Задачі розроблено для здобувачів вищої освіти за першим (бакалаврським) рівнем, що отримують спеціальність вчителя технологій, викладача з професійної освіти (на базі Херсонського державного університету) та спеціальність «Будівництво та цивільна інженерія» (на базі Херсонського державного аграрного університету). Доведено, що навчальна задача стає навчальною тільки в комплексі 3 попередніми та наступними, тобто у складі системи задач. Продемонстровано, що кожна наступна задача обов'язково повинна містити елементи попередньої, проте умови їх використання, а також формулювання або позначення раніше розглянутих понять мають бути новими. Виконання багаторазово повторюваних операцій 3 одними й тими ж поняттями та з варіацією вихідних даних і форми постановки питань сприяє виробленню
\end{abstract}

Corresponding Author: Dubovyk Liudmyla Petrivna. Phone: 0508046478. E-mail: kafphilosophy@ukr.net Kherson State Agrarian University, vul. Strytenska, 23, Kherson, Ukraine, 73006.

Відповідальний автор: Дубовик Людмила Петрівна. Тел. 0508046478. E-mail: kafphilosophy@ukr.net Херсонський державний аграрний університет, вул. Стрітенська, 23, м. Херсон, Україна, 73006. 
вмінь і навичок розв'язувати технічні задачі у майбутній професійній діяльності. Зазначено, що вирішення навчальних задач вимагає від майбутнього фахівця знань з основ різних наук й умінь ефективно застосовувати знання в кожній конкретній ситуації. Зокрема, при розв'язанні навчальних технічних задач студенти використовують знання з креслення (аналізуючи графічно задані умови задачі, схематично зображаючи свої пропозиції), з фізики (механіка, електрика і магнетизм, оптика), розвивають особистісні здібності до аналізу, критичної оцінки, узагальнення, систематизації. Використання навчальних технічних задач у підготовці майбутніх фахівців $€$ важливим елементом їхнього творчого розвитку, оскільки їх розв'язання сприяє інтегрованому застосуванню знань студентів. Розв'язання системи навчальних технічних задач створює умови для самостійної роботи та для активізації навчального процесу.

Ключові слова: конструкторсько-технологічна підготовка, дисципліни професійно-практичної підготовки, задача, навчальна задача, технічна задача, система навчальних задач.

\title{
Конструирование системы учебных задач по предметам профессионально-практической подготовки для будущих учителей технологий и специалистов по профессиональному образованию
}

\author{
Дубовик Л. П.
}

\author{
ГВУЗ «Херсонский государственный аграрный университет», Херсон, Украина
}

\begin{abstract}
Аннотация. Статья посвящена конструкторско-технологической подготовке специалистов инженернопедагогического направления с помощью использования системы учебных технических задач. Проведен анализ понятий «задача», «учебная задача», «техническая задача». Раскрыты особенности и содержание учебных задач. Приведены примеры учебных технических задач, которые используются при преподавании предметов профессионально-практической подготовки. Задачи разработаны для соискателей высшего образования первого (бакалаврского) уровня, которые получают специальность учителя технологий, преподавателя профессионального образования (на базе Херсонского государственного университета) и специальность «Строительство и гражданская инженерия» (на базе Херсонского государственного аграрного университета). Доказано, что учебная задача становится учебной, только в комплексе с предыдущими и последующими, то есть в системе задач. Продемонстрировано, как каждая следующая задача обязательно должна содержать элементы предыдущей, однако условия их использования, а также формулировки или обозначения ранее рассмотренных понятий должны быть новыми. Выполнение многократно повторяющихся операций с одними и теми же понятиями и с вариацией исходных данных и формы постановки вопросов способствует выработке умений и навыков решать технические задачи. Указано, что решение творческих задач требует от будущего специалиста знаний по основам различных наук и умений эффективно применять знания в каждой конкретной ситуации. В частности, при решении технических задач студенты используют знания по черчению (анализируя графически заданные условия задачи, схематично изображая свои предложения), по физике (механика, электрика и магнетизм, оптика), развивают личностные способности к анализу, критической оценки, обобщения, систематизации. Использование учебных технических задач в подготовке будущих специалистов является важным элементом их творческого развития, поскольку их решение технических способствует интегрированной применению знаний студентов. Решение системы учебных технических задач создает условия для самостоятельной работы и для активизации учебного процесса.
\end{abstract}

Ключевые слова: конструкторско-технологическая подготовка, дисциплины профессионально-практической подготовки, задача, учебная задача, техническая задача, система учебных задач.

\section{Bcmyn}

Метою професійно-практичної підготовки майбутнього фрахівця, пише Т. Якимович, є «розвиток важливих для професійної діяльності здібностей, виховання потреб і мотивів, пов'язаних з професією, формування професійних знань, умінь та навичок» [24, с. 8].

Органічною складовою професійно-практичної підготовки здобувачів вищої освіти за першим (бакалаврським) рівнем, що отримують спеціальність вчителя технологій, викладача з професійної освіти (на базі Херсонського державного університету) та спеціальність «Будівництво та цивільна інженерія» (на базі Херсонського державного аграрного університету) $є$ конструкторсько-технологічна підготовка, яка забезпечується шляхом навчання їх вирішенню навчальних технічних задач.

Вирішення (розв'язання) навчальних технічних задач у свою чергу має на меті досягнення освітніх і розвивальних цілей. При чому, освітня ціль спрямована на підготовку фахівця до виконання профресійної діяльності певного рівня кваліфікації, на набуття певних умінь і навичок, розвивальна - на 
розвиток профресійно важливих якостей майбутнього фахівця, зокрема на розвиток логічного мислення.

Аналіз психолого-педагогічних досліджень довів відсутність єдності у трактуванні поняття «задача» й існування цілого ряду підходів до визначення його сутності: діяльнісний підхід (В. Давидов, О. Леонтьєв, С. Рубінштейн та ін.); системний підхід (Л. Фридман, Є. Машбіц); власне задачний підхід (Г. Балл); ситуаційний підхід (К. Абульханова-Славська, В. Вербицький, Я. Пономарьов).

Під задачею, як вважає В.О. Моляко, розуміється самостійна проблема, що задається, формулюється або міститься в умові задачі, потребує від суб'єкта певної дії при пошуку відповіді на те чи інше запитання [18].

У свою чергу А. М. Матюшкін, розглядаючи питання використання задач з метою створення проблемних ситуацій, трактує поняття «задача», як спосіб знакового подання завдання однією людиною іншій, який вказує на мету і умови її досягнення [15].

Задачу Г. О. Балл розглядає як систему, обов'язковими складовими якої є: предмет задачі, який знаходиться у вихідному стані, та модель потрібного стану предмету задачі, яка ототожнюється 3 вимогами задачі [2].

У психологічній науці вводиться поняття «навчальна задача» як предмет теоретичного та практичного дослідження (М. Басов, Г. Бал, Л. Виготський, О. Леонтьєв, С.Рубінштейн, У. Рейтман, В. Давидов, Д. Ельконін та ін.).

У педагогічній науці проблема використання навчальних задач в освітньому процесі розглядалася І. Буслаєвим, С. Шохор-Троцьким, Ф. Ерном, П. Каптеревим, Л. Фридманом, І. Лернером та ін. У психолого-педагогічних дослідженнях висвітлювалися різноманітні аспекти навчальної задачі: як педагогічного засобу організації навчального процесу (Г. Балл, В. Гузєєв, В. Давидов, Д. Ельконін, Г. Костюк, Л. Фридман та ін.); як засобу розвитку творчих здібностей (В. Андрєєв, Г. Вергелес, О. Матюшкін, І. Желєзнова та ін.); як засобу стимулювання пізнавальної діяльності (Т. Бочкарева, О. Шашенкова та ін.); як засобу розвитку особистісного потенціалу (А. Хуторський, В. Соколов, В. Сєріков, О. Дусавицький та ін.); як засобу формування контрольно-оцінювальної самостійності (В. Давидов, В. Рєпкін, Г. Цукерман та ін.).

У більшості робіт навчальна задача виступає як складна система інформації про якийсь об'єкт, або процес, в якому чітко визначена лише частина відомостей, а інша - невідома. Саме її і вимагається знайти, використовуючи наявні знання, відомі алгоритми рішення у поєднанні із самостійними припущеннями та пошуками оптимальних способів рішення. Згідно точці зору Ю.Машбиця, навчальна задача - це будь-яка задача, що пред'являється тому, хто навчається, якщо вона спрямована на досягнення навчальної мети [16, с. 77$]$.

Н. Стовба розглядає навчальну задачу як систему завдань, при виконанні яких студент засвоює загальні способи дій. Вона наголошує, що «навчальні задачі $€$ специфічними для окремого напрямку діяльності і в навчальній діяльності студента рішення задач - це не мета, а засіб досягнення мети, а саме, мети навчання» [21, с. 175].

Аналізуючи структуру навчальної діяльності І. Зимня вважає, що другим за рахунком (після мотивації), але головним по суті компонентом цієї структури є навчальна задача. Вона пропонується учню як певне навчальне завдання (формулювання якого надзвичайно істотне для його вирішення і результату) в певній навчальній ситуації, сукупністю яких представлений сам навчальний процес загалом [10, c.5].

Навчальну задачу І. Зимня розглядає як складну систему інформації про будь-яке явище, об'єкт, процес, в якій чітко визначена лише частина відомостей, а решта невідома. Вона може бути знайдена тільки на основі рішення задачі або відомостей, сформульованих таким чином, що між окремими поняттями, положеннями $є$ неузгодженість, протиріччя, що вимагають пошуку нових знань, докази, перетворення, узгодження тощо [10, с .6].

Ґрунтуючись на визначенні навчальної діяльності як специфічної діяльності суб'єкта з оволодіння узагальненими способами діяльності спрямованої на його саморозвиток на основі рішення за допомогою навчальних дій спеціально поставлених педагогом і розв'язуваних навчальних задач, І. Зимня відзначає, що навчальна задача - це основна одиниця навчальної діяльності [10, с.6].

У дослідженні І.Олійник виділено два основні підходи до визначення сутності поняття «навчальна задача»: 
1) навчальна задача як об'єкт мисленнєвої діяльності, у якому в діалектичній єдності представлені складові елементи (предмет, умова, вимога), отримання пізнавального результату можливе за умови розкриття співвідношення між відомими і невідомими елементами задачі;

2) навчальна задача як складна дидактична система, де в єдності, взаємозв'язку, взаємозалежності та взаємодії представлені компоненти (задачна система і система розв'язання), кожна з яких, у свою чергу, складається з елементів, що знаходяться у тій же динамічній залежності складових: предмета, умов, вимог задачі, методів, шляхів, прийомів і засобів [19, с. 11].

Навчальна задача може виступати в якості поставленої в певних умовах мети діяльності як ситуація, що потребує розв'язання, і як форма представлення навчального матеріалу.

$€$. Машбіц, як і Д. Ельконін, найбільш істотною особливістю навчальної задачі вважають спрямованість на суб'єкт, бо її рішення передбачає зміни не в самій «задачній структурі», а в суб'єкті, який її вирішує. Цю ж думку підтримує В Рєпкін, який знаходить «відмінність навчальної задачі від інших у тому, що їі результат не в зміні предмету, з яким діє учень, а в зміні самого учня як суб'єкта, і ця зміна полягає в оволодіння певними способами дії» [20, с. 18]. Перетворення в задачі важливі не самі по собі, а як засоби зміни суб'єкта. Інакше кажучи, навчальна задача є засобом досягнення навчальних цілей. 3 цієї точки зору істотними являються не вони самі, а засвоєння учнем певного способу дії.

Науковці розглядають навчальні задачі як засіб навчального впливу. На їхню думку, стати предметом діяльності навчальний матеріал може тільки тоді, коли він знаходить прояв у задачі. Задачу слід вважати тією узагальнюючою і обов'язковою формою викладу матеріалу, в якій він тільки і може бути залучений в навчальний процес. Таку точку зору відстоює Д. Богоявленський: «Будь-який зміст стає предметом навчання тільки тоді, коли він набуває для навчання вигляду певної задачі, яка спрямовує і стимулює навчальну діяльність» $[4$, с.3].

Одним 3 напрямів конструкторсько-технологічної підготовки фрахівців інженерно-педагогічного напряму $€$ навчання їх вирішенню технічних задач. У процесі дослідження ми брали до уваги думку, що висловлює М. Антонюк, подаючи визначення поняття «технічна задача», як проблемне чи не проблемне завдання інтелектуально-практичного характеру, виконання якого проходить у результаті узагальнення теоретичних і практичних знань [1].

Розв'язання технічних задач, як правило, не спрямоване на одержання об'єктивно нового результату. Їхнє вирішення не має на меті створення нової машини або пристрою.

Навчальна задача, як і будь-яка інша, розглядається в даний час як системне утворення (за Г.Балом), в якому обов'язкові два компоненти: предмет завдання в початковому стані і модель необхідного стану предмета задачі.

Зокрема, склад навчальної задачі детально розглянуто в роботах Л. Фридмана, Є. Машбіц. Ними виділяються мета (вимога), об'єкти, які входять до складу умови задачі, їх фуннкії. у трактуванні Л. Фридмана до складу будь-якої задачі входять одні й ті ж частини:

- предметна область - клас фіксованих позначених об'єктів, про які йде мова;

- відносини, які пов'язують ці об'єкти;

- вимога задачі - вказівка мети рішення задачі, тобто того, що необхідно встановити в ході рішення;

- оператор задачі - сукупність тих дій (операцій), які треба зробити над умовою задачі, щоб виконати її рішення.

У даному поданні поняття «спосіб вирішення» та «оператор» дуже близькі, але зручніше використовувати термін «спосіб вирішення».

До умов завдання та її вимог належать дане і шукане, і основна умова полягає в тому, щоб «висловити шукане через дане». Відзначається також важливість формулювання завдання за критеріями коректності та складності, де останнім $€$ об'єктивний показник, який співвідноситься 3 суб'єктивними труднощами або легкістю рішення задачі. Розв'язання задач будь-якої діяльності - це завжди одержання певних результатів - результатів обчислень, побудови, роботи тощо.

І. Голдін пропонує складати задачі в такій формі, яка забезпечувала б при їх виконанні запрограмовану послідовність дій студента. Ця послідовність має враховувати логіку предмета (теми) і припускати, що кожне поняття, яким оперує студент, являється мінімально закінченим елементом системи знань [5]. 
Ці пропозиції ми враховували під час розробки навчальних технічних задач з дисциплін професійно-практичної підготовки («Взаємозамінність, стандартизація та технічні вимірювання», «Теорія механізмів та машин», «Електротехніка з основами радіоелектроніки», «Електрообладнання та засоби автоматизації сільськогосподарського виробництва» та ін.), використання яких описано у статтях $[7,8]$.

Прототипом нашої системи є система задач, розроблена І. Білосевичем. Зокрема, у процесі дослідження, проведеного І. Білосевичем було розроблено систему задач, спрямовану на розвиток технічного мислення в процесі вивчення ряду навчальних дисциплін, що мають місце у підготовці майбутнього вчителя технологій. Дослідник здійснив аналіз курсів технічних дисциплін з позиції виявлення можливості використання для розвитку технічного мислення запропонованої системи завдань при викладанні технічних дисциплін Він вважає, що для розвитку технічного мислення в умовах навчання будь-якої технічної дисципліни, при вивченні якої використовуються задачі, в умовах різних форм організації занять (лабораторні, практичні, семінарські і т. ін.) може бути використана аналогічна система задач [3]. І. Білосевич виділяє такі принципи побудови системи задач: поступове підвищення їх складності; їхня спрямованість на розвиток усіх компонентів технічного мислення; орієнтація задач на сучасні проблеми техніки.

Метою роботи є проведення аналізу змісту понять «задача», «навчальна задача», «технічна задача», розкриття особливостей конструкторсько-технологічної підготовки фрахівців інженернопедагогічного напряму за допомогою використання системи навчальних технічних задач. Для досягнення цієї мети здійснено відбір навчальних технічних задач, що використовуються при викладанні предметів професійно-практичної підготовки, сплановано їх використання протягом навчального процесу таким чином, щоб кожна наступна задача обов'язково містила елементи попередньої, проте умови їх використання, а також формулювання або позначення раніше розглянутих понять було новими. Тобто було розроблено системи задач для кожної дисципліни.

\section{II Матеріал і методи дослідження}

Більшість відомих дослідників проблем дидактики навчання сходяться на думці про те, що в основі успішного розвитку повинна бути покладена діяльність, пов'язана з розв'язуванням відповідної системи задач $[2,4,10,16,17,24]$. Тому не випадково, що в багатьох дослідженнях, де розглядаються наукові основи навчального процесу у вищих закладах освіти, серед необхідних і достатніх умов навчальної діяльності, вказується на необхідність обірунтованого перетворення змісту навчання у відповідну систему задач.

О. Щирбул переконаний, що «використання технічних задач $є$ важливим елементом творчого розвитку майбутніх фахівців, оскільки розв'язання технічних задач сприяє інтегрованому застосуванню знань студентів» [23, с.149].

У дослідженнях І. Олійник, Н.І.Стовби, О.Щирбул та ін. відмічається, що розв'язування навчальних технічних задач найкраще дозволяє виявити закономірності і переваги в мисленнєвих діях студента і, якщо необхідно, в певній мірі впливати на протікання розумової діяльності.

Систематичне уведення до начального процесу технічних задач, безумовно, сприяє розвитку технічної творчості майбутніх фахівців, оскільки таке професійне виховання, на думку О.Кучми і В. Лукаша, «включає розхитування підвалин стандартного й шаблонного мислення, заохочення до творчості, винахідництва, сприяння самоактуалізації й самореалізації студентів у обраному напрямі технічної творчості» [13, с. 67].

Методична сторона використання технічних завдань (у тому числі й задач) досить повно розкрита у педагогіці вищої школи. Так, зорема Д.Чернілевський зазначає, що процес творчості, зазвичай, здійснюється поетапно і включає: прийняття задачі, усвідомлення протиріччя, що міститься в умові, створення й обґрунтування ідеї, формулювання технічної пропозиції, технічну розробку завдання, технологічний етап (проектування, моделювання й конструювання), верифікацію або перевірку (випробування об'єктів в роботі та оцінка результату творчого рішення). Отже, творчий компонент притаманний не лише кінцевому продукту такої діяльності, а стосується кожного етапу виконання творчого завдання [22, с. 17]. 
Ю. Калязін переконаний, що формування творчих здібностей - це складний і довготривалий процес, що потребує використання в процесі навчання проблемних особистісно орієнтованих методів навчання. 3 метою реалізації останнього ефективним $€$ застосування викладачем навчальних $\mathrm{i}$ навчально-творчих задач [11, с.12].

У роботах Д. Ельконіна, В. Давидова, Г. Балла та ін. наголошується, що практично вся навчальна діяльність повинна бути представлена як система навчальних задач. Вони даються в певних навчальних ситуаціях і припускають певні навчальні дії - предметні, контрольні та допоміжні (технічні).

Навчальна задача як форма організації змісту навчального матеріалу передбачає наступну послідовність діяльності студента після ознайомлення з індивідуальним завданням: (за В. Барко): 1 аналіз запитання задачі і з'ясування, що дано, що потрібно знайти; 2 - визначення, які дані необхідні для відповіді на запитання задачі; 3 - з'ясування, чи всі необхідні дані наведено в умові задачі (якщо ні, визначення засобу знаходження відповідних величин); 4 - планування послідовності операцій, спрямованих на знаходження відповіді (алгоритм розв'язання); 5 - реалізація запланованих шляхів розв'язку; 6 - перевірка розв'язку задачі.

Повністю навчальною задача стає тільки в комплексі з попередніми і наступними, тобто в системі задач.

Звідси, за Є. Машбіцем, випливає ряд вимог.

1. «Конструювати необхідно не одну окрему задачу, а набір задач».

2. «При конструюванні системи задач треба прагнути, щоб вона забезпечувала досягнення не тільки найближчих навчальних цілей, а й віддалених».

3. «Навчальні задачі повинні забезпечити засвоєння системи засобів, необхідної і достатньої для успішного здійснення навчальної діяльності».

4. «Навчальна задача повинна конструюватися так, щоб відповідні засоби діяльності, засвоєння яких передбачається в процесі вирішення задачі, виступали як прямий продукт навчання» [16].

Як зауважує Є. Машбіц, для вирішення задачі суб'єкт-вирішувач повинен мати у своєму розпорядженні деяку сукупністю засобів, які не входять до задачі і залучаються ззовні. Засоби рішення можуть бути матеріальними (інструменти, машини), матеріалізовані (тексти, схеми, формули) та ідеальними (знання, які залучаються вирішувачем). У навчальній задачі можуть бути використані всі засоби, але провідними є ідеальні, вербальні за формою засоби [17].

Наприклад, розв'язання задачі з теоретичної механіки, що наведено вище передбачає виконання студентами наступних дій:

1. Вибрати точку, рівновагу якої необхідно розглянути для визначення шуканих величин.

2. Відкинути в'язі, які діють у стрижнях і замінити їх дію на шарнір (точку) відповідними силами реакції. Реакції в'язей направити від шарніра, прийнявши попередньо, що в стрижнях діють розтяжні зусилля.

3. Вибрати систему координат, початок координат зіставити з точкою, рівновага якої розглядається.

4. Скласти рівняння рівноваги для плоскої системи збіжних сил:

$$
\sum_{i=1}^{n} F_{i x}=0, \sum_{i=1}^{n} F_{i y}=0 .
$$

5. Визначити реакції стрижнів із рішення вказаної системи рівнянь рівноваги.

6. Виконати перевірку правильності отриманих результатів графічним методом.

Наведемо приклади деяких з них.

«Теорія механізмів та машин». За заданою кінематичною схемою (приклади схем наведено на рис. 1) та вихідними даними $\left(\omega, m 1, m 1, m 3, J_{S_{1}}, J_{S_{2}}, J_{S_{3}}\right.$, ) визначити інерціальне навантаження ланок механізмів, Розміри ланок механізмів визначити за масштабом кінематичних схем $\mu \ell=0,004$ M/MM.

Здійснити зрівноваження обертових мас, які лежать в площині, що містить вісь обертання валу, якщо задані величини і положення цих мас. 

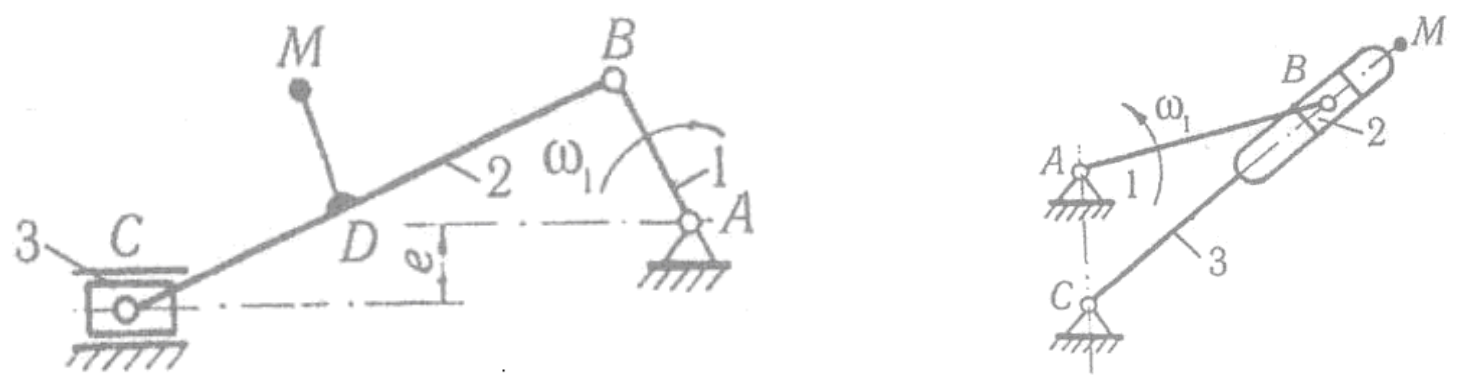

Рис. 1. Приклади схем до задачі з предмета «Теорія механізмів та машин»

«Теоретична механіка». За заданою схемою (приклади схем наведено на рис.2) та вихідними даними (F1, F2) визначити реакції двох шарнірно з'єднаних між собою стрижнів, що утримують два вантажі. Кріплення стрижнів у точках A, B, C шарнірне. Масою стрижнів знехтувати. Трос, що перекинутий через блоки являється невагомим і нерозтяжним.
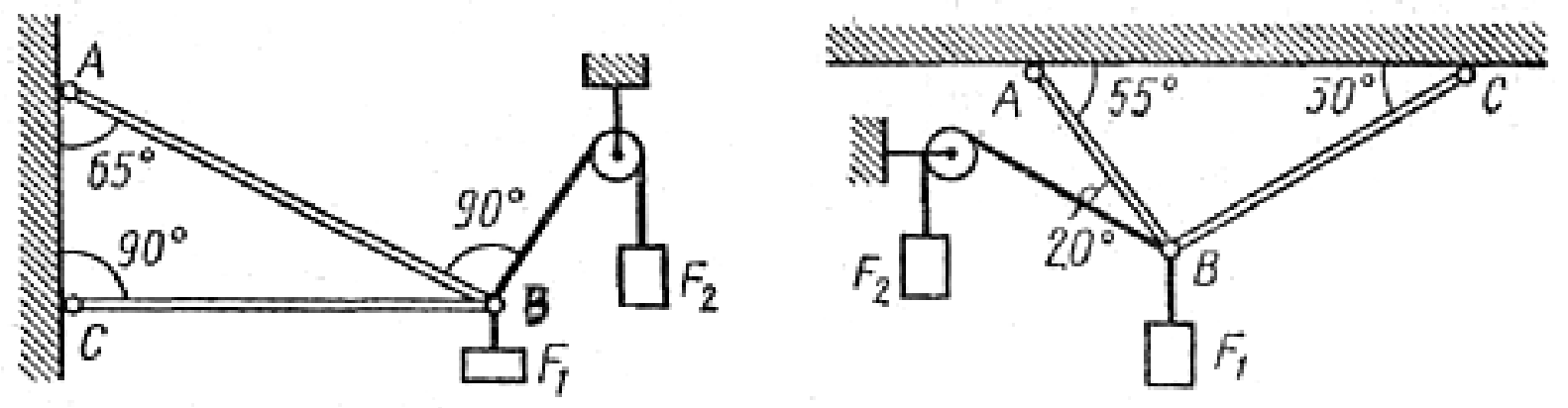

Рис. 2. Приклади схем до задачі з теоретичної механіки

«Опір матеріалів». Для заданого ступінчастого стрижня (приклади стрижнів наведено на рис. 3) та вихідними даними ( $\ell, a, b, P 1, P 2, P 3, m$, матеріал) визначити розміри поперечного перетину на всіх ділянках за умови, що форма перетину - коло, побудувати епюри нормальних напружень і поздовжніх переміщень стрижня.
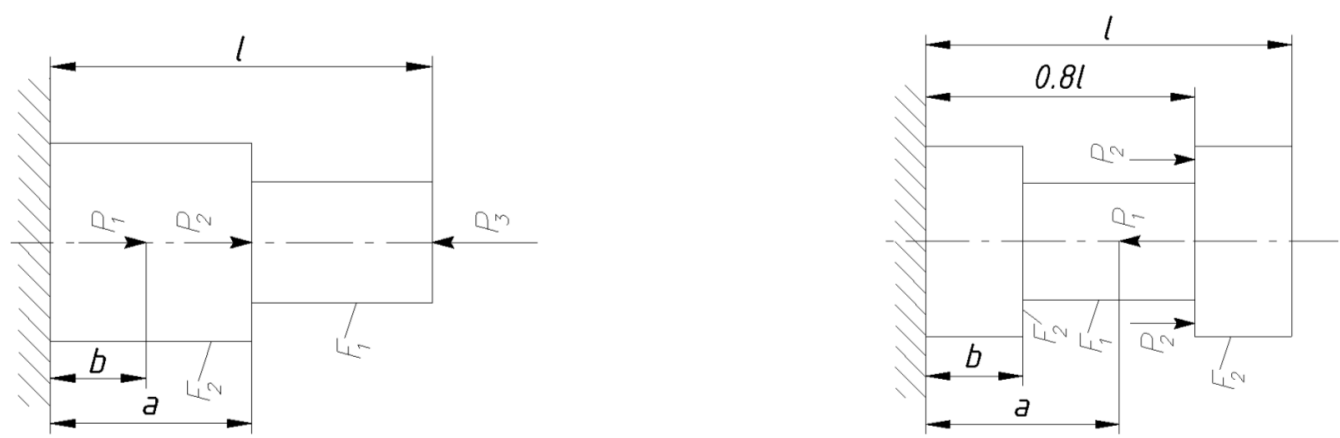

Рис. 3. Приклади стрижнів до задачі з опору матеріалів

«Електротехніка з основами радіоелектроніки». Розрахувати переріз алюмінієвих проводів для магістралі з навантаженням в 16 кВт довжиною 200 м від трансформаторної підстанції з номінальним вторинним напругою 380/220 В до житлового будинку, якщо допустима втрата напруги магістралі складає $5 \%$.

«Електрообладнання та засоби автоматизації сільськогосподарського виробництва». Розрахувати нагрівальний елемент за робочим струмом і таблицями навантаження. Виконати вибір пускозахисної апаратури для реалізації блокіровок у схемах автоматичного керування електроприводами сільськогосподарського призначення.

Задачі, приклади яких наведено, входять до змісту розроблених практикумів, навчальних посібників (наприклад: Кострицький В.Г., Дубовик Л.П. Теоретична механіка. Практикум для здобувачів 
ступеня вищої освіти «бакалавр» спеціальності 015 Професійна освіта (Технологія виробництва і переробка продуктів сільського господарства) та 015 Професійна освіта (Транспорт) денної та заочної форм навчання / В.Г.Кострицький, Л.П.Дубовик. - Херсон: Видавництво ХДУ, 2016. - 88 с.; Кострицький В.Г., Дубовик Л.П. Теорія механізмів і машин. Практикум до змістовного модуля «Структурний та кінематичний аналіз плоских механізмів» для студентів денної та заочної форм навчання галузі освіти 0101 «Педагогічна освіта» напряму підготовки 6.010104. Професійна освіта. Механізація сільськогосподарського виробництва та гідромеліоративних робіт /В.Г.Кострицький, Л.П.Дубовик. Херсон: Видавництво ХДУ, 2011. - 136 с.). Достатня кількість варіантів задач дозволяє видати кожному студенту індивідуальне завдання.

Процес розв'язування запропонованих задач вимагає від студента постійної розумової діяльності, зокрема, він аналізує, систематизує, здійснює групування даних умов, здійснює інші розумові операції, що сприяє розвитку його мислення. За допомогою таких навчальних задач об'єктивні дані, що викладені на лекціях викладачем, у підручниках, що спостерігаються на лабораторних і практичних заняттях перетворюються в суб'єктивні знання студентів. Тому від навчальних задач залежить і якість знань, їх сталість, рівень узагальненості, практичне застосування тощо.

Покажемо, як реалізуються ці міркування при конструюванні системи навчальних задач 3 дисципліни «Взаємозамінність, стандартизація та технічні вимірювання», що ввійшли до практикуму із змістового модуля «Загальні положення взаємозамінності і стандартизації. Системи допусків та посадок» [12].

Використовуючи посібник О. Єгорова та С. Стародубова [9], ми підбирали задачі так, щоб кожна наступна задача обов'язково містила елементи попередньої, проте умови їх використання, а також формулювання або позначення раніше розглянутих понять були новими. Таким чином, в процесі виконання системи навчальних задач при вивченні дисципліні «Взаємозамінність, стандартизація та технічні вимірювання» відбувається оперування, що багаторазово повторюється, одними й тими ж поняттями з варіацією вихідних даних і форми постановки питань.

Як показує практика викладання, варіювання несуттєвими ознаками понять у вихідних даних безсумнівно надає задачам навчальний характер і сприяє міцному засвоєнню як самих понять, так $\mathrm{i}$ способів оперування ними. Виконання навчальних задач відбувається на практичних заняттях і припускає обов'язкову наступну роботу студента над своїми помилками під керівництвом викладача.

\section{III Результати і обговорення}

Стрижнем навчальних задач, які студенти виконують на початковому етапі вивчення дисципліни «Взаємозамінність, стандартизація та технічні вимірювання», $є$ оперування первинними поняттями в процесі вирішення типової виробничої задачі - визначення ступеня придатності дійсного розміру. При цьому первинні поняття - розміри, відхилення, допуск, поле допуску - співвідносилися тільки з одним гладким елементом деталі.

На наступному етапі вивчення дисципліни студентам видаються навчальні задачі, спрямовані на розширення галузі застосування первинних понять. Таке розширення необхідно як для введення нових понять - зазор, натяг, посадка, групи посадок, так і тому, що первинні й нові поняття можуть характеризуватися не тільки числовими величинами, а й умовними (літерними) позначеннями.

Розглянемо чотири задачі, що входять до системи навчальних задач, які для зручності виконання та перевірки подаються в матричній формі.

Задача № 1. Розрахувати найбільші та найменші граничні розміри та допуски розмірів, граничні зазори (натяги) для заданих номінальних розмірів і граничних відхилень. Побудувати схему полів допусків для заданих номінальних розмірів і граничних відхилень.

Мета: навчити студентів визначати характер з'єднання.

Виконується під час практичної роботи №2 «Визначення номінальних розмірів, показників точності деталей циліндричних з'єднань і типу посадок» [12, с. 16]. Індивідуальні вихідні дані до задачі містять назву машини, агрегату або механізму, назву деталей, що спрягаються, та запис розміру за кресленням. Наприклад: пусковий двигун ПД - 1 ОУ (картер - Ø47+0,025, шарикопідшипник - Ø470,011 ). 
При виконанні задачі студенти оперують вже відомими первинними поняттями. У той же час це оперування відбувається в нових умовах. Новизна полягає в необхідності зіставлення граничних розмірів і полів допусків двох сполучених деталей, що мають однакові номінальні розміри. Таке зіставлення призводить до нової якості: дозволяє виявити нові поняття і вчитися оперувати ними.

Виконуючи задачу, студенти тричі подумки здійснюють спряження, оскільки їм задані розділені креслення деталей, що сполучаються. Задача передбачає можливість встановлювати всі групи посадок: із зазором, натягом і перехідні.

Результати виконання задачі студенти заносять до матриці, зразок якої наведено у таблиці 1. Використання матриць прискорює перевірку та оцінювання роботи студента.

Табл. 1. Матриця виконання студентами задачі №1

\begin{tabular}{|c|c|c|c|c|c|}
\hline \multirow{2}{*}{\multicolumn{2}{|c|}{ Контрольні запитання }} & \multirow{2}{*}{ 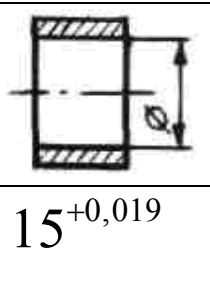 } & \multirow[b]{2}{*}{$15 \pm 0,006$} & $\pi a_{1}^{4}$ & \multirow[b]{2}{*}{$15_{-0,018}^{-0,006}$} \\
\hline & & & & $15_{+0,020}^{+0,032}$ & \\
\hline \multirow{7}{*}{ 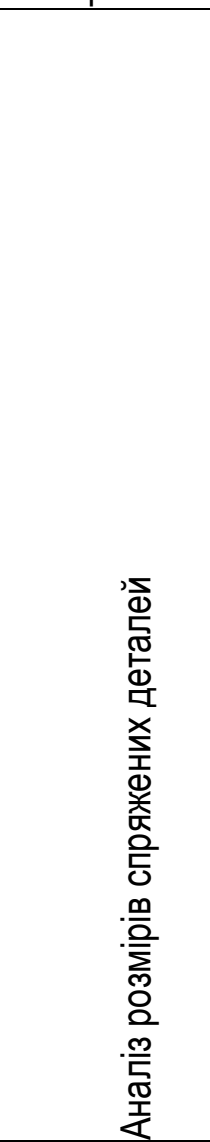 } & $\begin{array}{l}\text { Номінальний } \\
\text { розмір, мм }\end{array}$ & 15 & 15 & 15 & 15 \\
\hline & $\begin{array}{l}\text { Верхнє } \\
\text { граничне } \\
\text { відхилення, мм }\end{array}$ & $+0,019$ & $+0,006$ & $+0,032$ & $-0,006$ \\
\hline & $\begin{array}{l}\text { Нижнє } \\
\text { граничне } \\
\text { відхилення, мм }\end{array}$ & 0 & $-0,006$ & $+0,020$ & $-0,018$ \\
\hline & $\begin{array}{l}\text { Найбільший } \\
\text { граничний } \\
\text { розмір, мм }\end{array}$ & 15,019 & 15,006 & 15,032 & 14,994 \\
\hline & $\begin{array}{l}\text { Найменший } \\
\text { граничний } \\
\text { розмір, мм }\end{array}$ & 15 & 14,994 & 15,020 & 14,982 \\
\hline & $\begin{array}{l}\text { Допуск } \\
\text { розміру, мм }\end{array}$ & 0,019 & 0,012 & 0,012 & 0,012 \\
\hline & $\begin{array}{l}\text { Граффічне } \\
\text { зображення } \\
\text { поля допуску }\end{array}$ & $\begin{array}{r}+0,019 \\
0 \text { Om6 }\end{array}$ & $\frac{\underbrace{+0,006}_{-0,006}}{\underbrace{\prime}_{\mathrm{Ban}}}$ & $\begin{array}{c}+0,032 \\
\frac{\text { Ban }}{+0,020}\end{array}$ & $\underbrace{}_{\frac{-0,006}{-0,018}} 0$ \\
\hline $\begin{array}{l}\text { Визначення } \\
\text { характеру } \\
\text { з'єднання }\end{array}$ & Група посадки & & $\begin{array}{l}\text { Посадка } \\
\text { перехідна }\end{array}$ & $\begin{array}{l}\text { Посадка } \\
\text { натягом }\end{array}$ & $\begin{array}{ll}\text { Посадка із } \\
\text { зазором }\end{array}$ \\
\hline
\end{tabular}

Задача № 2. Визначити граничні відхилення отвору та валу для заданих посадок. Розрахувати найбільші та найменші розміри отворів та валів, найбільші та найменші зазори або натяги, допуск посадки. Побудувати схеми полів допусків. Виконати фрагменти робочих креслень деталей та фрагменти складального креслення, вказавши поля допусків умовними позначеннями та числовими значеннями граничних відхилень. Дати характеристики заданих посадок, вказати чи $є$ вони посадками переважного використання. 
Під час виконання другої задачі студенти так само, як і в задачі № 1, повинні навчитися визначати характер з'єднання. Однак у вихідних даних $є$ дві принципові відмінності порівняно з попередньою задачею: замість окремих креслень деталей задане креслення з'єднання і характер спряження заданий не числовими величинами граничних відхилень, а поданий умовними позначеннями полів допусків (наприклад: $\varnothing 30 \mathrm{H7}$ / е8, $\varnothing 50 \mathrm{M7}$ / h6, $\varnothing 85 \mathrm{P} 6$ / h5).

Задача передбачає оперування позначеннями посадок як в системі отвору, так і в системі вала. Виконуючи задачу, студенти спочатку оцінюють пару в цілому, потім подумки виконують розробку складальної одиниці (на відміну від задачі № 1, де вони в думках виконували складання) і на завершення знову повертаються до оцінки спряження. Матрицю виконання студентами задачі №2 наведено у статті [8].

Задача № 3. Визначити граничні відхилення отвору та валу за ГОСТ 25347-82 для заданих посадок. Розрахувати найбільші та найменші розміри отворів та валів, їх допуски, найбільші та найменші зазори або натяги, допуск посадки. Встановити вид посадки. Побудувати схеми полів допусків і нанести необхідні позначення. Зробити висновки відносно точності виготовлення деталей заданого з'єднання, характеру посадки у з'єднанні та придатності вказаних дійсних розмірів деталей.

Мета: навчити прийомам визначення ступеня придатності дійсних розмірів. Виконується під час практичної роботи №3 «Визначення придатності деталей за заданим параметром та стандартом» [12, с. 29]. Індивідуальні вихідні дані до задачі містять назву машини, агрегату або механізму, назву деталей, що спрягаються, позначення посадки, дійсні розміри отвору та валу. Наприклад, пусковий двигун дизеля A - 01М: втулка верхньої головки шатуна, поршневий палець; позначення посадки - 18 F7/h5, дійсні розміри отвору - 18,015, валу - 17,886).

Під час виконання задачі студенти спочатку оперують уже відомими їм поняттями, проте новим у цьому випадку є спосіб виявлення цих понять - через розшифровку умовних позначень полів допусків після звернення до таблиць відповідних стандартів.

Номінальні розміри у вихідних даних цієї та попередньої задач підібрані так, щоб студенти при роботі з таблицями стандартних граничних відхилень зустрілися з розташуванням розмірів всередині інтервалів і на їх границях. Задача передбачає можливість навчити студентів оперувати зашифрованими поняттями, що відносяться як до зовнішнього, так і до внутрішнього елемента деталі.

Особливий інтерес для зміцнення системи первинних понять і розширення області їх застосування мають дві останні групи питань матриці, зразок заповнення якої наведено у табл. 2.

Студенти повинні давати диференційований висновок про придатність дійсного розміру (придатний, брак виправимий, брак остаточний) не шляхом зіставлення заданих конкретних дійсних розмірів з конкретними граничними відхиленнями (так вони виконували раніше), а шляхом аналізу узагальнених відомостей у відповідності із проведеним сортуванням деталей за допомогою граничних калібрів на три можливі групи.

Правильні відповіді на ці питання будуть означати, що студенти міцно засвоїли зміст і методи оперування найважливішими первинними поняттями, оскільки здатні використовувати їх у нових умовах. Адже номінальні розміри ПР (прохідної) і НЕ (непрохідної) сторін калібру - це не що інше, як граничні розміри перевірюваних деталей.

Задача № 4. Вибрати системи утворення посадок (валу або отвору) для з'єднань, що відмічені розмірними лініями. Призначити для цих з'єднань, виходячи із умов роботи вид посадки (з зазором, натягом, перехідну). Виконати фрагмент креслення з'єднання, на якому вказати вибрані посадки, розміри спряжених поверхонь вибрати довільно згідно з рядом нормальних лінійних розмірів ГОСТ 6636-69.

Метою виконання цієї задачі $є$ набуття практичних навичок з вибору системи утворення посадок, квалітету та виду посадок у з'єднаннях деталей машин. Виконується під час практичної роботи №4 «Вибір системи посадок, квалітету та виду посадок» [12, с. 41].

Приклади вихідних даних до задачі №4 наведено на рис. 4.

$€$. Машбіц відзначає наступне: щоб учні, вирішуючи навчальні завдання, усвідомлено виконували і контролювали свої дії, вони повинні мати чіткі уявлення про структуру і засоби вирішення задачі. Такі відомості вони повинні отримувати від вчителя у вигляді стрункої системи орієнтування. [17]. Враховуючи цю думку до практикуму включено приклади вирішення задачі. 
Табл. 2. Матриця виконання студентами задачі №3

\begin{tabular}{|c|c|c|c|}
\hline \multicolumn{2}{|c|}{$\mathrm{Z}_{2}$ Вихідні дані } & $\begin{array}{l}\text { 究 } \\
0 \\
0\end{array}$ & $\begin{array}{r}5 \\
3 \\
8 \\
8 \\
+1\end{array}$ \\
\hline \multirow{7}{*}{$\begin{array}{lr}\text { Аналіз розмірів } \\
\text { спряжених деталей }\end{array}$} & Квалітет & 7 & 7 \\
\hline & Номінальний розмір, мм & 65 & 65 \\
\hline & Верхнє граничне відхилення, мм & $-0,030$ & $+0,009$ \\
\hline & Нижнє граничне відхилення, мм & $-0,060$ & -0.021 \\
\hline & Найбільший граничний розмір, мм & 64,970 & 65,009 \\
\hline & Найменший граничний розмір, мм & 64,940 & 64,979 \\
\hline & Допуск розміру, мм & 0,030 & 0,030 \\
\hline \multirow{5}{*}{$\begin{array}{l}\text { Висновок про } \\
\text { придатність } \\
\text { дійсних розмірів за } \\
\text { результатами } \\
\text { контролю } \\
\text { універсальними } \\
\text { вимірювальними } \\
\text { засобами }\end{array}$} & $64,945 \mathrm{mM}$ & придатний & $\begin{array}{l}\text { брак } \\
\text { виправимий }\end{array}$ \\
\hline & $64,956 \mathrm{MM}$ & придатний & $\begin{array}{l}\text { брак } \\
\text { виправимий }\end{array}$ \\
\hline & $65,000 \mathrm{mM}$ & брак виправимий & придатний \\
\hline & $65,005 \mathrm{MM}$ & брак виправимий & придатний \\
\hline & $65,015 \mathrm{Mm}$ & брак виправимий & $\begin{array}{l}\text { брак } \\
\text { остаточний }\end{array}$ \\
\hline \multirow{3}{*}{$\begin{array}{l}\text { Відомості про } \\
\text { граничні калібри }\end{array}$} & Тип калібру & скоба & пробка \\
\hline & $\begin{array}{l}\text { Номінальний розмір ПР сторони калібру, } \\
\text { мм }\end{array}$ & 64,970 & 64,979 \\
\hline & $\begin{array}{l}\text { Номінальний розмір HЕ сторони калібру, } \\
\text { мм }\end{array}$ & 64,940 & 65,009 \\
\hline \multirow{3}{*}{$\begin{array}{l}\text { Висновок } \\
\text { придатність про } \\
\text { дійсних розмірів за } \\
\text { результатами } \\
\text { контролю } \\
\text { граничними } \\
\text { калібрами }\end{array}$} & ПР проходить, НЕ проходить & брак остаточний & $\begin{array}{l}\text { брак } \\
\text { остаточний }\end{array}$ \\
\hline & ПР проходить, НЕ не проходить & придатний & придатний \\
\hline & ПР не проходить, НЕ не проходить & брак виправимий & $\begin{array}{l}\text { брак } \\
\text { виправимий }\end{array}$ \\
\hline
\end{tabular}
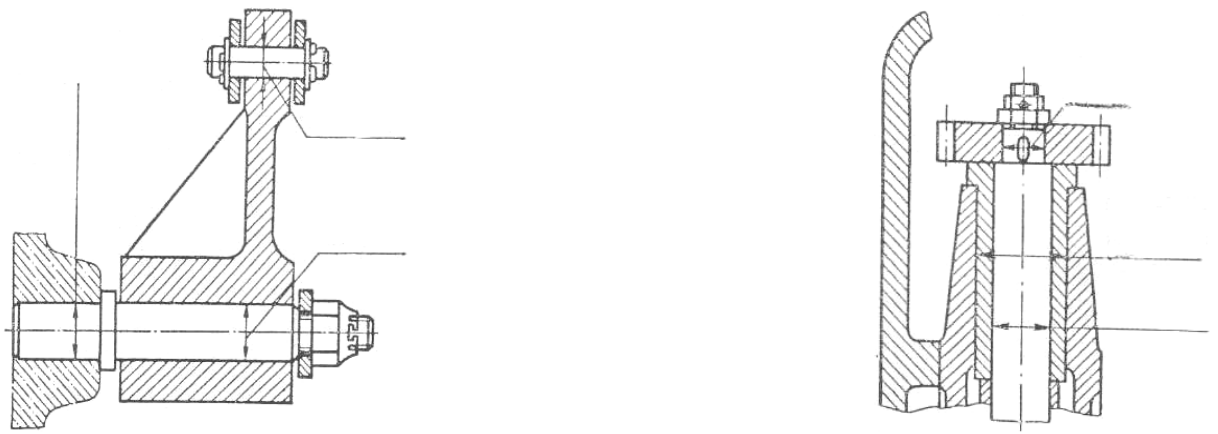

Рис. 4. Приклади вихідних даних до задачі №4

Зауважимо, що вибір виду посадки, системи посадок (отвору чи валу) і точності виготовлення деталей (квалітет) здійснюється одним з трьох методів: аналогів (прецедентів), подібності або розрахунковим.

Розрахунки, пов'язані з вибором посадок у нерухомих з'єднаннях зводяться до визначення міцності з'єднання, напружень і десормацій спряжених деталей. 
Виконання задачі починається з визначення принципу дії заданої складальної одиниці, що дає можливість обрати вид посадки (з натягом, перехідну або з зазором) в залежності від функцій складальної одиниці (з'єднання рухоме або нерухоме), необхідної точності центрування, наявності або відсутності додаткового кріплення деталей (шпонка, штифт), що передають крутний момент. У методичних рекомендаціях наведено короткі характеристики деяких видів посадок, особливості та застосування посадок з зазором, з натягом та перехідних посадок, описано області використання деяких посадок та приведені скороченні схеми розташування полів допусків посадок в системі отвору та валу для розмірів від 1 до 500 мм.

У виборі виду посадки студенти повинні перевагу віддавати посадкам переважного використання.

Під час виконання задачі студенти повинні проаналізувати доцільність використання тієї чи іншої системи утворення посадок.

Студенти вже знають, що посадки передбачені в системі отвору і в системі валу. Вони повинні розуміти, що для роботи з'єднання не має значення, у якій системі виготовлено спряжені деталі. Вибір системи визначається як складністю виготовлення (складання) деталей, так і вартістю виготовлення. Не дивлячись на те, що система отвору є економічно вигіднішою за систему валу, студенти не повинні її однозначно їі обирати. Слід пересвідчитись чи не відноситься задане у задачі з'єднання до випадків коли з конструктивних міркувань застосовують систему валу.

При виборі квалітету точності студентам потрібно призначати таку точність, яка при найменших затратах забезпечить задану працездатність та необхідну точність складання.

Зауважимо, що вибір оптимальної точності обробки являється складною техніко-технологічною задачею. При її рішенні студентам необхідно враховувати не тільки вартість обробки, яка збільшується при виборі більш точного квалітету, але й вартість складання, яка знижується з підвищенням точності обробки. Необхідно також враховувати вплив точності на експлуатаційні характеристики і економічні показники роботи машин (надійність, довговічність, коефріцієнт корисної дії, витрати пального та ін.).

Вибір квалітету студенти здійснюють у залежності від:

- точності об'єкта виробництва (машини, механізму або приладу), що обумовлюється його експлуатаційним призначенням;

- потрібного характеру з'єднань (виду посадок), що сприяє надійній роботі об'єкта в умовах експлуатації.

При виконанні задачі студенти засвоюють, що для більшості рекомендованих посадок $€$ характерним сполучення більш точних валів (на один квалітет) з менш точними отворами, що обумовлюється більшою трудомісткістю виготовлення отворів.

Зауваження: оскільки в цій задачі не передбачено оцінювання техніко-економічних показників обробки та роботи виробу, то вибір квалітету точності необхідно здійснювати на основі знань студентів щодо експлуатаційно-конструктивних вимог, що висуваються до роботи деталі та складальної одиниці загалом.

Результати використання системи навчальних задач у навчальному процесі переконливо свідчать про перспективність вибраного напряму в організації самостійної пізнавальної діяльності студентів на практичних заняттях з дисциплін професійно-практичної підготовки.

\section{V Висновки}

Отже, розв'язання навчальних технічних задач $є$ одним з важливих напрямів конструкторськотехнологічної підготовки фахівців інженерно-педагогічного напряму, оскільки технічна задача $\epsilon$ проблемним завданням інтелектуально-практичного характеру, виконання якого вимагає узагальнення теоретичних і практичних знань.

Під час вирішення системи навчальних задач студенти виконують запрограмовану послідовність дій, що має враховувати логіку предмета (теми) і припускати, що кожне поняття, яким оперує студент,є мінімально закінченим елементом системи знань.

Було враховано, що задача стає навчальною тільки в комплексі з попередніми і наступними - у системі задач: кожна наступна задача обов'язково повинна містити елементи попередньої, проте умови їх використання, а також формулювання або позначення раніше розглянутих понять мають бути новими. Це робиться з метою необхідності виконання операцій, що багаторазово повторюються, 3 
одними й тими ж поняттями та з варіацією вихідних даних і форми постановки питань.

Вирішення навчальних технічних задач завжди вимагає від майбутнього фахівця значних розумових зусиль. Більшість запропонованих задач носить проблемний характер, що сприяє застосуванню не тільки вже відомих студентам фрормул, теорем, законів для аналізу поставлених проблем, а й спонукає їх до знаходження і оволодіння новими знаннями, уміннями. Деякі задачі потребують додаткового опрацювання навчального матеріалу, зокрема із фахових або суміжних дисциплін. Розв'язання системи навчальних технічних задач створює умови для самостійної роботи та для активізації навчального процесу. При цьому у студента накопичується певний досвід застосування знань, відбувається формування необхідних операцій аналізу, синтезу, абстракції, формування узагальнень шляхом зіставлення окремих випадків з поступовим виділенням загального, широким варіюванням несуттєвих ознак, що сприяє розвитку прийомів логічного пошуку.

Система навчальних технічних задач важливий засіб навчання і контролю. Психолого-дидактична функція навчальних завдань пов'язана з перетворенням об'єктивних знань, що присутні в різних джерелах, у суб'єктивні, самостійно отримані знання; з управлінням процесом становлення й удосконалювання розумової діяльності студентів. При розв'язанні навчальної задачі студенти за допомогою навчальних дій узагальнено відкривають і опановують рішення цілого класу однорідних індивідуальних задач. Навчальні задачі відповідають вимогам технологічного підходу до навчання. Вони $€$ засобом проектування навчальних дій студентів та інструментом діагностики рівня засвоєння знань $\mathrm{i}$ сформованості широкого кола умінь.

\section{Бібліографрічні посилання}

1. Антонюк М.С. Розвиток пізнавальної активності учнів 5-7 класів загальноосвітньої школи в процесі розв'язування технічних задач: дис... канд. пед. наук: 13.00.01; АПН України, Ін-т педагогіки. К., 1993. 162 с.

2. Балл Г.А. Теория учебных задач: Психолого-педагогический аспект. М.: Педагогика, 1990. 184 с.

3. Білосевич І.А. Розвиток технічного мислення у майбутніх вчителів технологій в процесі вивчення спеціальних дисциплін: автореф. дис. на здобуття наук. ступеня канд. пед. наук: 13.00 .02 - теорія та методика трудового навчання. Чернігів, 2011. 20 с.

4. Богоявленский Д. М. Психология усвоения знаний в школе. М.: АН, 1959. 346 с.

5. Голдин И. Обучающие задания по «Допускам и техническим измерениям. Профтехобразование. 1988. № 9. С.16-18.

6. Горбатюк Р. М. Моделювання як метод побудови процесу формування творчих здібностей майбутніх інженерівпедагогів комп'ютерного профілю. Комп'ютерно-орієнтовані технології: освіта, наука, виробництво. 2011. Випуск 3. С. $86-91$.

7. Дубовик Л.П. Використання технічних задач при викладанні дисципліни «Техніко-технологічне проектування». Проектна та конструкторсько-технологічна підготовка майбутніх фахівців інженерного та педагогічного напрямів: Збірник наукових праць. 2011. С. 34-38.

8. Дубовик Л.П. Використання навчальних задач при викладанні дисциплін профресійно-практичної підготовки. Проектна та конструкторсько-технологічна підготовка майбутніх фахівців інженерного та педагогічного напрямів: Збірник наукових праць. 2011. С.40-46.

9. Егоров А.А. Пособие к решению задач курса взаимозаменяемость, стандартизация и технические измерения. М.: Высшая школа, 2003. $142 \mathrm{c.}$

10. Зимняя И.А. Учебная деятельность - специфический вид деятельности. Инновационные проекты и программы 8 образовании. 2009. №.6. С.3-13.

11. Калязін Ю. В. Інженерно-педагогічна творчість у підготовці інженерів-педагогів. Науковий журнал «Молодий вчений». 2018. № 5.3 (57.3). С. 9-15.

12. Кострицький В.Г., Дубовик Л.П. Взаємозамінність, стандартизація та технічні вимірювання. Практикум до змістового модуля «Загальні положення взаємозамінності і стандартизації. Системи допусків та посадок» для студентів денної, заочної та екстернатної форм навчання галузі знань 0101.Педагогічна освіта напряму підготовки 6.010104. Профресійна освіта. Херсон: Видавництво ХДУ, 2014. 160 с.

13. Кучма О. Формування технічної творчості студентів технолого-педагогічних та інженерно-педагогічних спеціальностей. Збірник наукових праць УДПУ ім. Павла Тичини. 2019. Вип. 1. С. 63-69.

14. Масич В. В. Роль творчості у професійній діяльності майбутнього інженера-педагога. Педагогіка та психологія. Вип. 56. Харків, 2017. С. 257-265.

15. Матюшкин А.М. Проблемные ситуации в мышлении и обучении. М.: Директмедиа Паблишинг, 2008. 392 с.

16. Машбиц Е.И. Психологические основы управления учебной деятельностью. К.: Вища школа, 1987. 191 с.

17. Машбиц Е. И. Психологический анализ учебной задачи. Сов.педагогика. 1973. № 2. С. 58-65.

18. Моляко В. А. Психология решения школьниками творческих задач. К.: Наукова думка, 1983. 284 с.

19. Олійник І. Розв'язання професійно-педагогічних задач як необхідна складова майстерності викладача вищої школи. Педагогіка і психологія професійної освіти. 2016. № 1. С. 7-24. 
20. Репкин В.В. Развивающее обучение и учебная деятельность. Рига: Эксперимент, 1997. 40 с.

21. Стовба Н. І. Навчальна діяльність студентів як система навчальних задач. Актуальні проблеми психології. Т.7, вип. 20. Ч. 2., - 2011 C. $175-178$.

22. Чернілевський Д. В. Педагогіка вищої школи: підручник. Вінниця: Глобус-прес, 2010. 408 с.

23. Щирбул О.М. Розв'язання технічних задач як важлива компонента інтеграції знань майбутніх фахівців із технічної творчості. Наукові записки КДПУ ім. Володимира Винниченка. Серія: Проблеми методики фізико-математичної і технологічної освіти. 2011. Вип. 1. С. 146-149.

24. Якимович Т. Д. Основи дидактики професійно-практичної підготовки. Львів, 2013. 138 с.

\section{References}

1. Antoniuk, M.S. (1993). Development of educational activities of 5-7 classes of foreign schools in the process of development of technical tasks [Rozvytok piznavalnoi aktyvnosti uchniv 5-7 klasiv zahalnoosvitnoi shkoly v protsesi rozviazuvannia tekhnichnykh zadach]. Pedagogic science candidate theses, 13.00.01, APN of Ukraine, Institute of Pedagogics, Kyiv, 162. [in Ukrainian]

2. Ball, G.A. (1990). Theory of educational problems: Psychological and pedagogical aspect [Teoriia uchebnykh zadach: Psikhologo-pedagogicheskii aspekt]. Pedagogika, Mosccow, 184. [in Russian]

3. Bilosevych, I.A. (2011). The development of technical thinking in future technology teachers in the study of special subjects [Rozvytok tekhnichnoho myslennia u maibutnikh vchyteliv tekhnolohii $v$ protsesi vyvchennia spetsialnykh dystsyplin]. Pedagogic science candidate author's abstract, 13.00 .02 - Theory and methodology of labor training, Chernihiv, 20. [in Ukrainian]

4. Bogoiavlenskii, D. M. (1959). Psychology of assimilation of knowledge in school [Psikhologiia usvoeniia znanii v shkole]. AN, Moscow, 346. [in Russian]

5. Goldin, I. (1988). Educational tasks on "Tolerances and technical measurements [Obuchaiushchie zadaniia po «Dopuskam i tekhnicheskim izmereniiam]. Vocational education [Proftekhobrazovanie], 9, 16-18. [in Ukrainian]

6. Horbatiuk, R.M. (2011). Modeling as a method of constructing the process of forming the creative abilities of future computer engineers-educators [Modeliuvannia yak metod pobudovy protsesu formuvannia tvorchykh zdibnostei maibutnikh inzhenerivpedahohiv komp'iuternoho profiliu]. Computer-oriented technologies: education, science, production [Komp'iuterno-oriientovani tekhnolohii: osvita, nauka, vyrobnytstvo], 3, 86-91. [in Ukrainian]

7. Dubovyk, L.P. (2011). The use of technical tasks in teaching the discipline "Engineering and technological design" [Vykorystannia tekhnichnykh zadach pry vykladanni dystsypliny «Tekhniko-tekhnolohichne proektuvannia»]. Design and technological development of future specialists in engineering and pedagogical fields: Collection of scientific works [Proektna ta konstruktorsko-tekhnolohichna pidhotovka maibutnikh fakhivtsiv inzhenernoho ta pedahohichnoho napriamiv: Zbirnyk naukovykh prats], 34-38. [in Ukrainian]

8. Dubovyk, L.P. (2011). Use of educational tasks in teaching the disciplines of vocational training [Vykorystannia navchalnykh zadach pry vykladanni dystsyplin profesiino-praktychnoi pidhotovky]. Design and technological development of future specialists in engineering and pedagogical fields: Collection of scientific works [Proektna ta konstruktorsko-tekhnolohichna pidhotovka maibutnikh fakhivtsiv inzhenernoho ta pedahohichnoho napriamiv: Zbirnyk naukovykh prats], 40-46. [in Ukrainian]

9. Egorov, A.A. (2003). A guide to solving the problems of the course interchangeability, standardization and technical measurements [Posobie $\mathrm{k}$ resheniiu zadach kursa vzaimozameniaemost, standartizatciia i tekhnicheskie izmereniia]. Vysshaia shkola, Moscow, 142 [in Russian]

10. Zimniaia, I.A. (2009). Educational activity is a specific type of activity [Uchebnaia deiatelnost - spetcificheskii vid deiatelnosti]. Innovative projects and programs in education [Innovatcionnye proekty i programmy v obrazovanii], 6, 3-13. [in Ukrainian]

11. Kaliazin, Yu.V. (2018). Engineering and pedagogical creativity in training of engineers-pedagogues [Inzhenerno-pedahohichna tvorchist u pidhotovtsi inzheneriv-pedahohiv]. Scientific journal "Young scientist" [Naukovyi zhurnal «Molodyi vchenyi»], 5.3 (57.3), 9-15. [in Ukrainian]

12. Kostrytskyi, V.H., Dubovyk, L.P. (2014). Interchangeability, standardization and technical measurements. Workshop for the content module "General Interchangeability and Standardization. Admission and Landing Systems sfor full-time, part-time and extracurricular students in the field of knowledge 0101.Pedagogical education 6.010104. Professional education [Vzaiemozaminnist, standartyzatsiia ta tekhnichni vymiriuvannia. Praktykum do zmistovoho modulia «Zahalni polozhennia vzaiemozaminnosti i standartyzatsii. Systemy dopuskiv ta posadok» dlia studentiv dennoi, zaochnoi ta eksternatnoi form navchannia haluzi znan 0101.Pedahohichna osvita napriamu pidhotovky 6.010104. Profesiina osvita]. Vydavnytstvo KhDU, Kherson, 160. [in Ukrainian]

13. Kuchma, O. (2019). Formation of technical creativity of students of technological-pedagogical and engineering-pedagogical specialties [Formuvannia tekhnichnoi tvorchosti studentiv tekhnoloho-pedahohichnykh ta inzhenerno-pedahohichnykh spetsialnostei]. Collection of scientific works of Pavlo Tychyna UDPU [Zbirnyk naukovykh prats UDPU im. Pavla Tychyny], 1, 63-69. [in Ukrainian]

14. Masych, V.V. (2017). The role of creativity in the professional activity of a future engineer-teacher [Rol tvorchosti u profesiinii diialnosti maibutnoho inzhenera-pedahoha]. Pedagogy and psychology [Pedahohika ta psykholohiia], 56, 257-265. [in Ukrainian]

15. Matiushkin, A.M. (2008). Problem situations in thinking and learning [Problemnye situatcii v myshlenii i obuchenii]. Direktmedia Pablishing, Moscow, 392. [in Russian] 
16. Mashbitc, E.I. (1987). Psychological foundations of learning management [Psikhologicheskie osnovy upravleniia uchebnoi deiatelnostiu]. Vishcha shkola, Kyiv, 191. [in Ukrainian]

17. Mashbitc, E.I. (1973). Psychological analysis of the educational task [Psikhologicheskii analiz uchebnoi zadachi]. Soviet pedagogy [Sov.pedagogika], 2, 58-65. [in Russian]

18. Moliako, V. A. (1983). Psychology of solving school problems by students [Psikhologiia resheniia shkolnikami tvorcheskikh zadach]. Naukova dumka, Kyiv, 284. [in Ukrainian]

19. Oliinyk, I. (2016). Solving professional and pedagogical tasks as a necessary component of the mastery of a teacher of a high school [Rozviazannia profesiino-pedahohichnykh zadach yak neobkhidna skladova maisternosti vykladacha vyshchoi shkoly]. Pedagogy and psychology of vocational education [Pedahohika i psykholohiia profesiinoi osvity], 1, 7-24. [in Ukrainian]

20. Repkin, V.V. (1997). Developing education and training activities [Razvivaiushchee obuchenie i uchebnaia deiatelnost]. Eksperiment, Riga, 40. [in Russian]

21. Stovba, N.I. (2011). Educational activity of students as a system of educational tasks [Navchalna diialnist studentiv yak systema navchalnykh zadach]. Actual problems of psychology [Aktualni problemy psykholohii], 7(20), part 2, 175-178. [in Ukrainian]

22. Chernilevskyi, D.V. (2010). Pedagogics of higher education: textbook [Pedahohika vyshchoi shkoly: pidruchnyk]. Hlobus-pres, Vinnytsia, 408. [in Ukrainian]

23. Shchyrbul, O.M. (2011). Solving technical problems as an important component of integrating the knowledge of future technical professionals [Rozv'iazannia tekhnichnykh zadach yak vazhlyva komponenta intehratsii znan maibutnikh fakhivtsiv iz tekhnichnoi tvorchosti]. Scientific notes of Volodymyr Vinnychenko KSPU. Series: Problems of Methods of PhysicalMathematical and Technological Education [Naukovi zapysky KDPU im. Volodymyr Vynnychenka. Seriia: Problemy metodyky fizyko-matematychnoi i tekhnolohichnoi osvity], 1, 146-149. [in Ukrainian]

24. Yakymovych, T.D. (2013). Fundamentals of didactics of vocational training [Osnovy dydaktyky profesiino-praktychnoi pidhotovky]. Lviv, 138. [in Ukrainian]

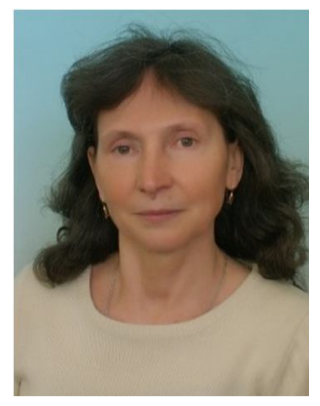

\section{Дубовик Людмила Петрівна.}

Кандидат педагогічних наук, доцент, доцент кафедри профресійної освіти,

Херсонський державний аграрний університет,

вул. Стрітенська, 23, м. Херсон, Україна, 73006.

Тел. 0508046478. E-mail: kafphilosophy@ukr.net

\section{Dubovyk Liudmyla Petrivna.}

Cand.Sc. (Pedagogical), Associate Professor, Associate Professor of Professional Education Department, Kherson State Agrarian University,

vul. Strytenska, 23, Kherson, Ukraine, 73006.

Phone: 0508046478. E-mail: kafphilosophy@ukr.net

ORCID: 0000-0003-2380-9155

\section{Citation (APA):}

Dubovik, L. (2020). Designing of system of educational task in the disciplines of professional and practical training for future technology teachers and professionals in vocational education. Engineering and Educational Technologies, 8 (1), 33-47. doi: https://doi.org/10.30929/2307-9770.2020.08.01.03

\section{Цитування (ДСТУ 8302:2015):}

Дубовик Л. П. Конструювання системи навчальних задач з предметів професійно-практичної підготовки для майбутніх вчителів технології та фахівців з професійної освіти / Інженерні та освітні технології. 2020. Т. 8. № 1. С. 33-47. doi: https://doi.org/10.30929/2307-9770.2020.08.01.03

Обсяг статmі: $\quad$ сторінок - 15 ; умовних друк. аркушів - 2,173. 